Original Paper

\title{
Penerapan Supervisi Klinis untuk Meningkatkan Aktivitas Siswa dan Kemampuan Guru IPA dalam Menerapkan Metode Experimen
}

\author{
Junaedi $1^{*}$ \\ 1 Sekolah Menengah Pertama Negeri 1 Gerung, Kabupaten Lombok Barat, NTB, Indonesia
}

DOI: https://doi.org/10.29303/jcar.v3i1.650

*Corresponding Author:

Junaedi, Sekolah

Menengah Pertama

Negeri 1 Gerung,

Kabupaten Lombok

Barat, NTB, Indonesia.

Email:

edi26022@gmail.com

\begin{abstract}
Abstrak: Tujuan penelitian tindakan sekolah (PTS) ini adalah untuk untuk meningkatkan kemampuan guru IPA kelas VII dalam menggunakan metode experimen dengan menerapkan supervisi klinis di SMP Negeri 1 Gerung Tahun Pelajaran 2018/2019. Subyek penelitian ini adalah guru IPA kelas VII SMP Negeri 1 Gerung. Penelitian dilakukan melalui penerapan supervisi klinis kepala sekolah sebagai upaya peningkatan aktivitas siswa dan kemampuan guru IPA dalam menggunakan metode experiment di SMP Negeri 1 Gerung. Penelitian dilakukan dengan 2 siklus yaitu siklus 1 dan siklus 2. Setiap siklus terdiri atas perencanaan, tindakan, pengamatan, dan refleksi. Analisis data dilakukan secara kuantitatif dan kualitatif. Hasil penelitian menunjukkan adanya peningkatan kemampuan guru IPA kelas VII dalam menerapkan metode experimen, pada saat penelitian dilakukan pada siklus 1 nilai rata rata mencapai $51,78 \%$ dengan kwalifikasi cukup dan meningkat pada siklus 2 menjadi $80,56 \%$ dengan kwalifikasi amat baik.
\end{abstract}

Kata kunci: Supervisi Klinis; Aktivitas Siswa; Kemampuan Guru; Metode Experimen

\section{Pendahuluan}

Tujuan Nasional Bangsa Indonesia yang tercantum pada pembukaan Undang-Undang Dasar 1945 alinea ke-4 antara lain untuk mencerdaskan kehidupan bangsa. Dipertegas lagi dalam Undang-Undang No. 20 Tahun 2003 Bab II Pasal 3 tentang Sistem Pendidikan Nasional yang menyatakan bahwa pendidikan Nasional berfungsi mengembangkan kemampuan dan membentuk watak peradaban bangsa yang bermartabat dalam rangka mencerdaskan kehidupan bangsa, bertujuan untuk mengembangkan potensi peserta didik agar menjadi manusia yang beriman dan bertaqwa kepada Tuhan Yang Maha Esa, berakhlak mulia, berilmu, cakap, kreatif, mandiri dan menjadi warga negara yang demokrasi serta bertanggung jawab.

Peran guru sangat penting untuk mendukung keberhasilan pendidikan oleh karena itu perlu bagi guru untuk dapat melaksanakan tugasnya dengan baik (Sopian, 2016). Guru dalam pembelajaran dihrapkan menggunakan berbagai pendekatan, strategi, dan metode pembelajaran yang dapat memudahkan peserta didik memahami materi yang diajarkannya (Siregar, 2013). Namun masih sering terdengar keluhan dari para guru di lapangan tentang materi pelajaran yang terlalu banyak dan keluhan kekurangan waktu untuk mengajarkannya.

Kemampuan guru merupakan syarat utama keberhasilan dalam kegiatan pembelajaran di kelas (Nurhaidah, 2014; Musa, 
2016). Keberhasilan seorang guru dalam melaksanakan tugasnya tidak hanya tergantung dari penguasaan materi pembelajaran, cara atau teknik-teknik penyampaian materi pelajaran, tetapi guru harus pandai dalam memilih metode pembelajaran yang sesuai dan mampu menggunakan metode pembelajaran secara efektif dan efisien (Ilyass \& Syahid, 2018).

Untuk meningkatkan kualitas kemampuan mengajar guru menuju peningkatan mutu pendidikan diperlukan metode mengajar yang variatif (Tyagita \& Iriani, 2018) dan tidak cukup hanya mengandalkan metode ceramah. Termasuk di dalamnya sarana dan prasarana belajar guna menunjang proses yang positif terhadap prestasi belajar siswa. Media pembelajaran merupakan bagian integral dari proses belajar mengajar, oleh sebab itu dalam pemilihan media harus melihat semua komponen dari perencanaan pembelajaran seperti tujuan, materi, pendekatan dan metode, serta bentuk evaluasi termasuk tingkat perkembangan intelektual siswa (Teni, 2018).

Mata pelajaran IPA lebih menekankan pada keterlibatan siswa secara langsung dalam mengkaji alam sekitar (Sulthon, 2017), untuk menganalisa (Tias, 2017), memahami konsepkonsep di dalamnya dan merumuskan hukum berdasarkan generalisasi dan memecahkan masalah dalam kehidupan sehari-hari berdasarkan hukum IPA secara memadai (Sulthon, 2017). Oleh karena itu, pada mata pelajaran IPA dapat kita lihat bahwa, siswa akan belajar efektif apabila mereka terlibat secara langsung dalam pengorganisasian dan pertemuan berhubungan dengan informasi yang dihadapinya.

Kenyataan di lapangan banyak dijumpai metode mengajar guru belum maksimal. Guru cenderung mengajar kurang bervariasi, dan ceramah merupakan senjata yang paling ampuh yang menyebabkan para siswa menjadi cepat bosan dan memiliki kecendrungan berfikir bahwa pelajaran IPA adalah pelajaran yang sulit difahami, banyak hafalan dan pada akhirnya mereka malas mengikuti pelajaran IPA.

Permasalahan metode mengajar guru banyak mengalami hambatan dan permasalahan, namun untuk mengatasi hambatan dan permasalahan itu seharusnya guru menggunakan metode yang variatif dan khusus pada pelajaran IPA metode experimen mutlak digunakan untuk membangkitkan semangat belajar siswa.

Dengan metode eksperimen ini siswa dapat lebih percaya atas kebenaran atau kesimpulan berdasarkan percobaannya sendiri daripada hanya menerima kata guru atau buku, dapat mengembangkan sikap untuk mengadakan studi eksplorasi (menjelajahi) tentang ilmu dan teknologi dan dengan metode eksperimen ini siswa akan terbina menjadi manusia yang dapat membawa terobosan-terobosan baru dengan penemuan sebagai hasil percobaan yang diharapkan dapat bermanfaat bagi kesejahteraan hidupmanusia.

Berdasarkan uraian tersebut dilakukan penelitian penelitian tindakan sekolah (PTS) tentang penerapan supervisi klinis untuk meningkatkan kemampuan guru IPA kelas VII dalam menggunakan metode experiment di SMP Negeri 1 Gerung tahun pelajaran 20182019.

\section{Metode}

\section{Subyek Penelitian}

Subyek dalam penelitian ini adalah guru IPA kelas VII di SMP Negeri 1 Gerung yang merupakan tempat peneliti menjadi kepala sekolah tahun pelajaran 2018/2019.

\section{Setting Penelitian}

Penelitian ini dilakukan pada guru IPA kelas VII SMP Negeri 1 Gerung Lombok Barat tahun pelajaran 2018-2019. Guru IPA kelas VII SMP Negeri 1 Gerung tahun pelajaran 20182019 sebanyak 3 orang yang terdiri dari 2 orang guru IPA Pendidikan S1 biologi, dan 1 orang guru IPA Pendidikan S1 fisika. PTS 
dilakukan melalui penerapan supervise klinis kepala sekolah sebagai upaya peningkatan aktivitas siswa dan kemampuan guru IPA kelas VII dalam menggunakan metode experiment di SMP Negeri 1 Gerung tahun pelajaran 2018-2019.

\section{Rancangan Penelitian}

Rancangan penelitian ini terdiri atas: (1) Tindakan dilakukan dalam 2 siklus; (2) Kegiatan dilaksanakan dalam semester genap tahun pelajaran 2018-2019; (3) Lama penelitian 4 pekan efektif dimulai 18 Oktober sampai dengan 18 November 2019; (4) Dalam pelaksanaan tindakan, rancangan dilakukan dalam 2 siklus yang meliputi: (a) perencanaan, (b) Tindakan (c) pengamatan (d) refleksi.

Menurut Arikunto, (2010) rancangaan penelitian tindakan sekolah seperti gambar berikut:

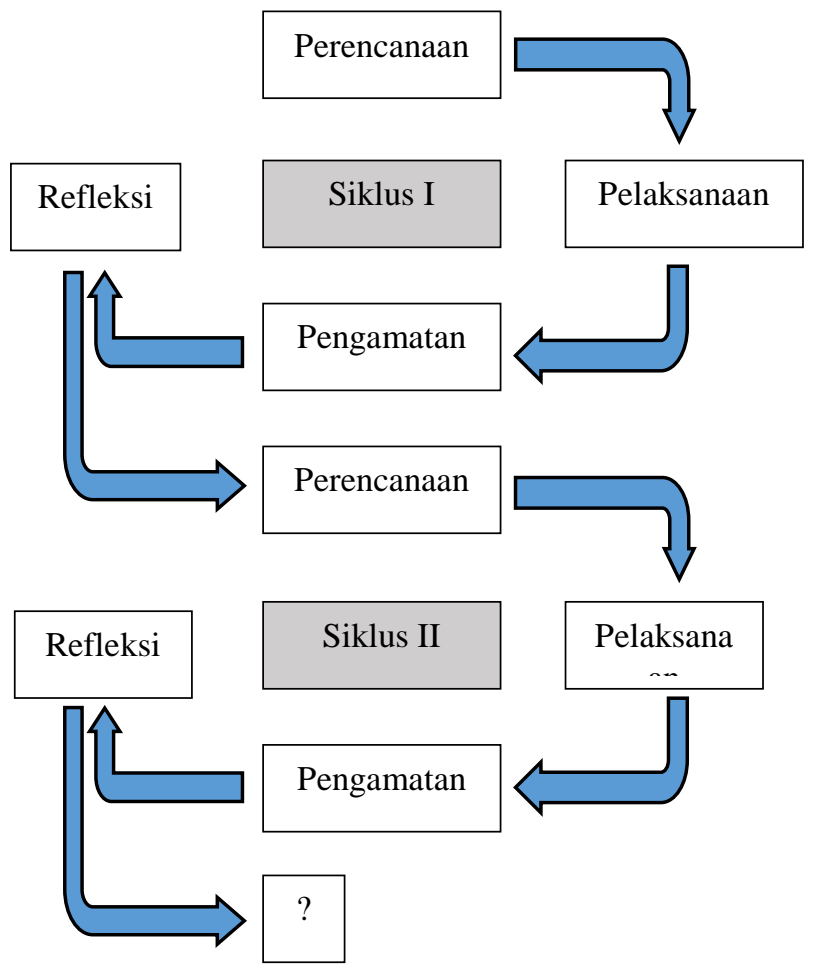

Gambar 1. Rancangan Penelitian Tindakan Kelas (PTS)

\section{Perencanaan}

Tahapan ini berupa rancangan tindakan yang menjelaskan tentang apa, mengapa,kapan, dimana,oleh siapa dan bagaimana tindakan tersebut dilakukan. Pada
PTS ini peneliti dan guru adalah orang yang berbeda, dalam tahap menyusun rancangan harus ada kesepakatan antara keduanya. Rancangan harus dilaakukan bersama antara guru yaang melakukan tindakan dengan peneliti yang akan mengamati proses jalannya tindakan, Hal tersebut untuk mengurangi unsur subyektivitas pengamat serta mutu kecermatan pengamatan yang dilakukan.

\section{Tindakaan.}

Pada tahap ini, rancangan tindakan tersebut tentu saja sebelumnya telah dilatih kepada si pelaksana tindakan (guru) untuk dapat di terapkan di dalam kelas sesuai dengan skenarionya. Skenrio dari tidakan harus dilaksanakan dengan baik dan wajar.

\section{Pengamatan atau Observasi}

Tahap ini sebenarnya bersamaan dengan waktu pelaksanaan tindakan, jadi pengamatan dilakukan pada waktu tindakaan sedang berjalan. Pada tahap ini peneliti melakukan pengamatan dan mencatat semua hal yang diperlukan dan terjadi selama pelaksanaan tindakan berlangsung. Pengumpulan data ini menggunakan format observasi yang disusun, termasuk juga pengatan terhadap proses dan hasil pembelajaran.

\section{Refleksi.}

Tahapan in dimaksudkan untuk mengkaji secara menyeluruh tindakan yang telah dilakukan, berdasarkan data yang telah terkumpul, kemudian dilakukan evaluasi untuk menyempurnakan tindakan berikutnya. Refleksi dalam PTS mencakup analisis,sintesis, terhadap hasil pengamatan dan tindakan yang dilakukan. Jika terapat permasalahan dalam proses refleksi maka dilakukan proses pengkajian ulang melalui siklus berikutnya yang meliputi kegiatan; perencaaan ulaang, tindakan ulang, dan pengamatan ulang sehingga permasalahan dapat teratasi. 


\section{Sumber dan Teknik Pengumpulan Data}

Sumber data dalam penelitian ini berasal dari dua sumber yaitu guru dan kepala sekolah. Teknik Pengumpulan data dalam penelitian ini adalah menggunakan observasi dan angket.

\section{Indikator Keberhasilan}

Penelitian Tindakan Sekolaah (PTS) yang dilaksanakan dalam 2 siklus dianggap sudah berhasil apabila terjadi peningkatan kemampuan guru IPA Kelas VII dalam menggunakan metode experimen mencapai 85\% (Guru yang diteliti) telah mencapai ketuntasan dengan nilai rata rata $75 \%$, berarti telah memenuhi harapan ideal seperti yang disyaratkan dalam manajemen berbasis sekolah ( MBS ) dengan standar ideal 75\%.

\section{Teknik Analisa Data}

Dalam analisis data Teknik yang digunakan adalah: (1) Kuantitatif, analisis ini di gunakan untuk menghitung besarnya peningkatan kemampuan guru IPA kelas VII dalam menggunakan metode experiment melalui penerapan supervise klinis kepala sekolah dengan menggunakan prosentase (\%); (2) Kualitatif, Teknik analisis ini digunakan untuk memberikan gambaran hasil penelitian secara reduksi data, sajian deskriptif, penarikan simpulan. Jenis instrument yang digunakan dalam penelitian ini adalah lembar observasi kegiatan guru, dan lembar observasi kegiatan siswa.

\section{Hasil dan Pembahasan}

\section{Siklus I}

\section{Tahap Perencanaan}

Pada tahap ini peneliti mempersiapkan perangkat pembinaan yang terdiri dari rencana tindakan, dan alat pembinaan lain yang mendukung. Selain itu dipersiapkan lembar observasi aktivitas siswa dan lembar observasi peningkatan kemampuan guru IPA kelas VII dalam menggunakanmetode experiment melalui supervise klinis.

\section{Tahap Kegiatan dan Pelaksanaan}

Pelaksanaan kegiatan pembinaan untuk siklus 1 dilaksanakan pada tanggal 15 oktober sampai dengan tanggal 21 oktober 2019 di SMP Negeri 1 Gerung tahun pelajaran 2018-2019. Dalam hal ini peneliti bertindaak sebagai kepala sekolah, adapun proses pembinaan mengacu pada rencana pembinaan yang telah disiapkaan.

Pengamataan (observasi) di laksanakaan bersamaan dengan pelaksanaan proses pembelajaran di sekolah, pada akhir proses pembinaan guru di beri angket isian 1 dengan tujuan untuk mengetahui tingkat keberhasilan guru dalam menggunakanmetode experimen sesuai dengan pedoman yang telah di tentukan.

Adapun kemampuan guru IPA dalam melaksanakan pembelajaran dengan menggunakan metode exprimen, supervisor mengunanakan lembar obserbasi instrumen kunjungan kelas pada siklus 1 dapat di lihat pada tabelberikut.

Tabel 1. Kemampuan guru IPA kelas VII dalam menggunakan metode experiment,

\begin{tabular}{llll}
\hline No & Nama Guru & Nilai & Ket \\
\hline 1 & Abdurrahmaan, S.Pd & $51,75 \%$ & Cukup \\
2 & Sri Fitriani S.Pd & $55,35 \%$ & Cukup \\
3 & Sri Hartaati, S.Pd & $48,21 \%$ & Cukup \\
\hline
\end{tabular}

Dari 14 aspek lembar observasi kunjungan kelas yang dinilai untuk guru IPA Pendidikan S1 biologi dengan nilai persentase 51,75\% dan $48.21 \%$ dengan kwalifikasi cukup, sedangkan untuk guru IPA Pendidikan S1 fisika dari 14 aspek yang dinilai memperoleh nilai persentasi 55,35 \%.dengan kwalifikasi cukup.

\section{Refleksi}

Berdasar hasil observasi tersebut diatas pada persentase kemampuan guru IPA Pendidikan S1biologi dalam menggunakan metode experimen baru tercapai sekitar $52 \%$ dan guru IPA S1 fisika $55 \%$ dengn katagori atau kwalifikasi cukup dan belum mencapai 
kwalifikasi baik, maka perlu dilakukan perbaikan pada siklus ke 2 .

Dalam pelaksanaan kegiatan pembinaan sesuaai informsi diatas tentantang instrument supervise kunjungan kelas maka hasil pengamatan pada siklus 1 menunjukkan hal sebagai berikut:

(1) Guru IPA memiliki nilai rata rata masih kurang dalam hal menyelenggarkan kegiatan dengan urutan yang logis dan membimbing siswa mengikuiti kegitan secara individu dan kelompok.

(2) Guru IPA belum memahami penjelasan yang disampaikan oleh kepala sekolah terkait pelaksanaan supervise kllinis

(3) Guru IPA belum memahami isi instumen kunjungan kelas dan isi lembar observasi yang di gunakan oleh oleh kepala sekolah dalam mealkukan pembinaan.

(4) Kepala sekolah dalam melakukan supervise kunjungan kelas masih kurang baik dalam pemanfaatan waktu

(5) Kepala sekolah belum maksimal dalam melalukan pembinaan terhadap guru IPA Kelas VII, karena masih banyaknya tugas daan pekerjaan yang harus segera diselesaikan.

\section{Revisi rancangan}

Pelaksanaan kegiatan pembinaan pada siklus I masih terdapat kekurangan, sehingga perlu adanya revisi untuk penyempurnaan yang akan dilakukan pada siklus berikutnya.

1) Kepala sekolah melalui daftar pertanyaan setelah observasi mengingatkan atau memberi catatan di lembar obsevasi pada guru IPA kelas VII tentang kekurangan guru dalam pelaksanaan pembelajaran dengan menggunakan metode experiment di siklus 1 sehingga kemampuannya pada siklus 2 meningkat.

2) Kepala sekolah menjelaskan kembali maksud dan tujuan pembinaan supervise klinis kepada guru IPA kelas II yang akan menerapkan metode experiment di siklus 2 sehingga guru IPA dapat melaksanakan tugasnya dengan lebih baik.
3) Kepala sekolah mengulangi penjelasannya tentang instrument kunjungan kelas dan lembar obsrvasi yang dilakukan dalam melakukan pembinaan bagi guru IPA kelas VII.

4) Kepala sekolah perlu mendistibuskan waktu secara baik dengan menambah informas informasi yang dirasa perlu dan memberi catatan.

5) Kepala sekolah haarus lebih terampil dan bersemangat dalam memotivasi guru sehingga kemampuannya lebih meningkat.

6) Kepala sekolah memaksimalkan waktu dalam melakukan pembinaan terhadap guru IPA kelas VII dengan harapan pada siklus 2 kemampunnya lebih meningkat.

\section{Siklus 2}

\section{Tahap Perencanaan}

Pada tahap ini peneliti mempersipkan perangkat pembinaan yang terdiri dari rencana pembinaan, daftar pertanyaan sebelum dan setealh observasi, insntrumen supervise kunjungan kelas siklus 2, dan alat pembinaan lainnya yang mendukung.

\section{Tahap kegiatan dan Pengamatan}

Pelaksanaan pembinaan pada siklus II dilakukan pada tanggal 1 november 8 november 2019 di SMP Negeri 1 Gerung tahun 2018-2019. dalam hal ini peneliti bertindak sebagai kepala sekolah. Adapun proses pembinaan mengacu pada rencana pembinaan dengan memperhatikan revisi pada siklus I, sehingga kesalahan atau kekurangan pada siklus I tidak terulang kembali pada siklus II. Pengamatan (Observasi) dilaksanakan bersamaan dengan pelaksanaan proses belajar mengajar di sekolah.

Pada akhir proses pembinaan guru diberi angket isian II dengan tujuan untuk mengetahui tingkat keberhasilan guru dalam dalam meningkatkan kemampuannya yang telah dilakukan. Instrumen yang digunakan adalah daftar pertanyaan setelah observasi .

Adapun kemampuan guru dalam melaksanakan pembelajaran dengan 
menggunakan metode exprimen dapat di lihat pada table 2 .

Tabel 2.

\begin{tabular}{llll}
\hline No & Nama Guru & Nilai & keterangan \\
\hline 1 & Abdurrahmaan, S.Pd & $80,35 \%$ & Amat baik \\
2 & Sri Fitriani S.Pd & $85,71 \%$ & Amat baik \\
3 & Sri Hartati, S.Pd & $75,21 \%$ & Baik \\
\hline
\end{tabular}

Dari 14 aspek lembar observasi kunjungan kelas, yang dinilai untuk guru IPA Pendidikan S1 biologi dengan nilai persentase $80,35 \%$ dengan kwalifikasi amat baik,dan nilai 75,21 dengan kwalifikasi baik, sedangkan untuk guru IPA S1 fisika dari 14 aspek yang dinilai memperoleh nilai persentasi 85,71 $\%$.dengan kwalifikasi amat baik.

Berdasar table diatas diperoleh nilai rata rata persentasi sebesar 80,42\%. .Hasil penelitian pada siklus II ini mengalami peningkatan yang signifikan dari siklus I. Adanya peningkatan hasil pembinaan pada siklus II ini dipengaruhi oleh adanya peningkatan peningkatan kemampuan kepala sekolah dalam melaksanakan pembinaan melalui supervise klinis sehingga guru menjadi lebih memahami tugasnya sehingga dapat meningkatkan kemampuananya. Disamping itu peningkatan ini dipengaruhi oleh kerjasama dari guru yang telah menguasai materi pembinaan untuk membantu guru lainnya yang belum menguasai materi pembinaan.

\section{Refleksi}

Pada tahap ini akan dikaji apa yaang telah dilaksanakan dengan baik maupun yang masih kurang baaik dengan proses pembinaan melalui suppervisi klinis kepala sekolah, dari data yang telah diperoleh dapat diuraikan sebagai berikut:

(1)Guru IPA kelas VII Selama proses pembinaan oleh kepala sekolah mengalami peningakatan jumlah nilai rata rata yang berarti kemampuan guru IPA kelas VII dalam menggunakan metode experiment meningkat, meskipun ada beberapa aspek yang belum sempurna, tetapi persentase pelaksanaannya untuk masing masing aspek sudah baik.

(2) Berdasarkan data hasil pengamatan diketahui bahwa guru IPA kelas VII memahami isi instrument kunjungan kelas dan observasi yang dilakukan kepala sekolah .

(3) Kekurangan pada siklus siklus sebelumnya sudah mengalami perbaikan dan peningkatan sehingga menjadi lebih baik.

(4) Hasil pembinaan guru IPA kelas VII oleh kepala sekolah melalui supervise klinis pada siklus II mengalami peningkatan yang signifikan.

\section{Revisi Pelaksanaan}

Pada siklus II Kepala Sekolah telah melaksanakan pembinaan dengan baik dan dilihat dari peningkatan kemampuan, pelaksanaan pembinaan sudah berjalan dengan baik, maka tidak diperlukan revisi terlalu banyak, tetapi yang perlu diperhatikan untuk tindakan selanjutnya adalah memaksimalkan dan mempertahankan apa yang telah ada dengan tujuan agar pada pelaksanaan pembinaan selanjutnya baik supervise klinis maupun supervise lainnya dapat meningkatkan kemampuan guru sehingga tujuan pembinaan atau supervise sebagai upaya meningkatkan kemampuan guru dapat tercapai dengan baik.

\section{Analisis Hasil Penelitian}

Setelah melakukan tindakan pada siklus I dan siklus II menunjukkan hasil sesuai Table 3. 
Tabel 3. Analisis Hasil Observasi kunjungan kelas Kepala Sekolah dalam Peningkatan kemampuan guru IPA kelas VII menggunakanmetode experimen melalui supervise klinis sebelum dan sesudah diberi tindakan.

\begin{tabular}{lllll}
\hline No Nama Guru IPA & $\begin{array}{l}\text { Skor Sebelum } \\
\text { diberi tindakan } \\
\text { Siklus 1 }\end{array}$ & Kualifikasi & $\begin{array}{l}\text { Skor setelah } \\
\text { diberi tindakan } \\
\text { Siklus 2 }\end{array}$ & Kualifikasi \\
\hline $1 \quad$ Abdurrhman, S.Pd & 51,78 & Cukup & 80,75 & Amat baik \\
$2 \quad$ Sri Fitriani S.Pd & 55,35 & Cukup & 85,71 & Amat baik \\
$3 \quad$ Sri Hartati, S.Pd & 48,21 & Cukup & 75,21 & Baik \\
Jumlah & 155,34 & & 241,67 & \\
Rata rata & 51,78 & & 80,56 & \\
Skor maksimum individu & 100 & & 100 & \\
Skor maksimum sekolah & 300 & 300 & \\
\hline
\end{tabular}

\section{Analisis Data Deskriptif Kuantitatif}

Pencapaian peningkatan kemampuan guru IPA kelas VII dalam menggunakan metode experimen melalui supervise klinis kepala sekolah sebelum diberi tindakan.

$$
\text { Skor }=\frac{155,34}{300} \times 100=51,78
$$

Pencapaian peningkatan kemampuan guru IPA kelas VII dalam menggunakan metode experiment melalui supervise klinis kepala sekolah setelah diberi tindakan

$$
\text { Skor }=\frac{241,67}{300} \times 100=80,56 \%
$$

Dari Analisa tersebut diatas dapat disimpulkan bahwa:

1) Terjadi peningkatan kemampuan guru IPA kelas VII dalam menggunakan metode experiment setelah diberi pembinaan melalui supervise klinis kepala sekolah yaitu peningkatan dari $51,78 \%$ menjadi $80,56 \%$, ada kenaikan sebesar $28,78 \%$.

2) Rata rata peningkatan kemampuan guru IPA kelas VII sebelum diberi pembinaan dari 51,78 \% (siklus I), naik menjadi 80,56\% pada siklus II.

3) Dari pembinaan pada siklus I, dan setelah pembinaan melalui supervise klinis kepala sekolah pada siklus II ada peningkatan kemampuan guru IPA kelas VII dalam menggunakan meotode experiment sebesar $80,56 \%-51,78 \%=28,78 \%$.

\section{Refleksi dan Temuan}

Berdasarkan pelaksanaan pembinaan yang telah dilakukan kepala sekolah melalui supervise klini suntuk meningkatkan kemampuan guru IPA Kelas VII yang menggunakan metode experiment di SMP negeri 1 Gerung tahun pelajaran 2018-2019, maka hasil observasi nilai dapat dikatakan sebagai berikut:

1) Guru IPA kelas VII dalam menerapkan metode experiment siklus 1 terlihat masih lemah pada penyelenggaraan kegiatan dengan urutan yang logis dan dalam membimbing siswa ketika melakukan experiment baik secara individu maupun kelompok.

2) Kepala sekolah dalam melakukan pembinaan melalui supervise klinis belum maksimal sehingga nlai yang diperoleh oleh guru IPA kleas VII masih dalam kwalifikasi cukup.

3) Pada siklus 2 terjadi peningkatan nilai rata rataguru IPA kelas VII dalam menerapkan metode experiment hal ini di pengaruhi oleh kemampuan guru dalam haal memaknaai hasil pembinaan dan bimbingan oleh kepala sekolah melalui observasi kunjungan kepalaa sekolah.

4) Pada siklus 2 proses pembinaan berjalan dengan baik, semua guru IPA kelas VII lebih aktif karena guru telah memahami makna dari instrument kunjungan kelas dan observasi setelah mendapatkan penjelasan dari kepala sekolah dalam 
melakukan pembinaan melalui supervise klinis.

Hasil penelitian ini menunjukkan bahwa pembinaan melalui supervise klinis kepala sekolah mempunya dampak positif dalam meningkatkan aktivitas siswa dan kemampuan guru IPA kelas VII dalam menggunakan metode experimen, hal ini dapat dilihat dari semakin meningkatnya aktivitas siswa dan kemempuan guru terhadap pembinaan yang dilakukan oleh kepala sekolah, hasil instrument kunjungan kelas menunjukkan kemampuan guru meningkat dari siklus I ke siklus II yaitu dari 51,78\% menjadi 80,56\%. Kemampuan Kepala Sekolah dalam Meningkatkan Kemampuan Guru.

Berdasarkaan analisis data, diperoleh aktivitas siswa dan kemmampuan guru dalam setiap siklus mengalami peningkatan, hal ini berdampak positif terhadap peningkatan capaian mutu sekolah itu sendiri, hal ini dapat ditunjukkan dengan meningkatnya nilai rata rata guru IPA kelas VII dan aktivitas siswa pada siklus I dan skus II. Aktivitas Kepala Sekolah dan Guru dalam Pembinaan melalui Supervisi Klinis.

Berdsarakan analisis data, diperoleh aktivitas guru yang paling dominan dalam supervisi klinis adalah bekerja dengan menggunakan alat/media, mendengarkan, memperhaatikan penjelasan kepalaa sekolah, dan diskusi antara guru dan kepala sekolah. Jadi dapat dikatakan aktivitas guru dikatagorikan aktif. Sedangkan untuk aktivitas kepala sekolah selama pembinaan telah melaksanakaan langkah langkah dengan metode pembinaan melalui supervise klinis dengaan baik. Hal ini terlihat dari aktivitas kepala sekolah dalam membuat, merencanakan program, melaksankan supervise klinis, memberi umpan balik, evaluasi pelaksaan program, tanya jawab merupakan bentuk aktivitas kepala sekolah yang cukup besar.

Berdasarkan hasil penelitian diatas, dapat dikatakan peningkataan kemampuan guru IPA kelas VII melalui supervise klinis kepala sekolah hasilnya sangat baik. Hal ini dapaat dilihat pada data bahwa dari 3 orang guru IPA kelas VII pada saat penelitian dilakukan nilai rata rata mencapai 51,78 \% pada siklus 1 dan meningkat menjadi 80,56\% pada siklus 2, Dari analisis data diatas dinyatakan bahwa pembinaan yang dilakukan kepala sekolah melalui supervise klinis adalah efektif diterapkan dalam upaya meningkatkan kemampuan guru IPA kelas VII dalam menggunakan metode experiment di SMP Negeri 1 Gerung tahun pelajaran 22018-22019, yang berarti proses pembinaan kepala sekolah telah berhasil dan dapat meningkatkan capaian mutu sekolah khususnya di SMP Negeri 1 Gerung Lombok Barat NTB. Oleh karena itu diharapkan kepada para kepala sekolah untuk dapat melaksanakan pembinaan guru melalui supervise klinis secara berkelanjutan.

Berdasarkan Permen No.13 Tahun 2007 tentang kompetensi kepala sekolah, membuat Rencana Kerja Sekolah (RKS), serta dapat mengorganisasikan sekolah kearah perubahan yang diinginkan hingga mencapai 85\%, maka penerapan supervise klinis kepala sekolah untuk meningkatkan aktivitas siswa dan kemampuan guru IPA dalam menerapkan metode experiment di SMP Negeri 1 Gerung tahu pelajaran 2018-2019 dikatakan efektif. Dengan demikian maka hipotesis yang diajukan diatas dapat di terima.

\section{Kesimpulan}

Berdasarkan hasil analisis hasil penelitian dan pembahasan dapat disimpulkan bahwa: (1) Penerapan supervise klinis kepala sekolah berpengaruh pada meningkatnya kemampuan guru IPA kelas VII dalam menggnakan metode experiment di SMP Negeri 1 Gerung tahun pelajaran 20182019; (2) Efektivitas penerapan supervisi klinis kepala sekolah dalam meningaktkan kemmampuan guru IPA kelas VII menggunakan meode experiment di SMP 
Negeri 1 Gerung tahun pelajaran 2018-2019 dapat di lihat pada peningkatan nilai rata rata kemampuan guru IPA kelas VII dari siklus 1 ke siklus 2 yaitu dari 51,78\% menjadi 80,56\%, ada kenaikan sebesar 28,78.

\section{Daftar Pustaka}

Arikunto, S. (2010). Prosedur Penelitian Suatu Pendekatan Praktek. Rineka Cipta.

Ilyass, M., \& Syahid, A. (2018). Pentingnya Metodologi Pembelajaran Bagi Guru. Jurnal Al-Aulia, 04(01), 58-85.

Musa, M. I. (2016). Pengembangan Kompetensi Guru Terhadap Pelaksanaan Tugas Dalam Mewujudkan Tenaga Guru Yang Profesional. Jurnal Pesona Dasar, 2(4), 827.

Nurhaidah. (2014). Kompetensi Guru, Sumber Daya, Berkualitas. Jurnal Pesona Dasar, 2(3), 13-26.

Siregar, Y. (2013). Kompetensi Guru Dalam Bidang Strategi. Formatif: Jurnal Ilmiah Pendidikan MIPA, 3(1), 39-48.

Sopian, A. (2016). Tugas, Peran, Dan Fungsi Guru Dalam Pendidikan. Raudhah Proud To Be Professionals: Jurnal Tarbiyah Islamiyah, 1(1), 88-97. https://doi.org/10.48094/raudhah.v1i1.1 0

Sulthon, S. (2017). Pembelajaran IPA yang Efektif dan Menyenangkan bagi Siswa MI. ELEMENTARY: Islamic Teacher Journal, $4(1)$. https://doi.org/10.21043/elementary.v4i 1.1969

Teni, N. (2018). Kata Kunci :Pengembangan media pembelajaran untuk meningkatkan hasil belajar siswa. Jurnal Misykat, 03(01), 171.

Tias, I. W. U. (2017). Penerapan Model Penemuan Terbimbing Untuk Meningkatkan Hasil Belajar Ipa Siswa Sekolah Dasar. DWIJA CENDEKIA: Jurnal Riset Pedagogik, 1(1), 50-60. https://doi.org/10.20961/jdc.v1i1.13060

Tyagita, B. P. A., \& Iriani, A. (2018). Strategi
Peningkatan Kompetensi Pedagogik Guru Untuk Meningkatkan Mutu Sekolah. Kelola: Jurnal Manajemen Pendidikan, 5(2), 165-176. https://doi.org/10.24246/j.jk.2018.v5.i2.p $165-176$ 